Важливим постає вміння розуміти мотиви діяльності та вміння ставити завдання, які розкривали б перспективу за доступного донесення важливості та значущості досягнення мети.

Молодому спеціалісту притаманна ієрархія мотивів - від найбільш загальних, що характеризують спрямованість діяльності (концепція життя, система цінностей), - до ситуативних, пов'язаних із задоволенням певних потреб за конкретної ситуації.

Найвищим рівнем потреб (за фізіологічними) $є$ задоволення потреб у спілкуванні, повазі, незалежності тощо. Зауважимо, що соціальна природа будь-якої особистості відображається в мотивації на рівні потреб. Тому в професійній царині діяльності гірничого інженера значущими постають соціальні потреби спілкування; належного соціального становища; визнання іншими; самоствердження; самореалізації тощо.

Так, ще 3 давніх-давен робилися спроби пояснити поведінку людей, розкрити причини цілеспрямованої діяльності. 3 різних позицій розкривалися мотиваційні аспекти: активізація, стимулювання, управління, реалізація цілеспрямованої поведінки фахівця [2]. Не випадково значущим постає комплекс потреб суб'єкта, інтересів і взаємопов'язаних бажань, установок та ціннісних орієнтацій. Потреби та їх похідні (бажання, інтереси тощо)є суттєвими чинниками, які визначають лінію індивідуальної поведінки фахівця.

Отже, відповідність певних якостей гірничого інженера передовсім особливостям професійної діяльності $\epsilon$ пріоритетною умовою адаптованості особистості. Зокрема, професійної адаптації, що характеризується не лише пристосуванням, а входженням до активної фахової діяльності. Для молодого фахівця гірничої галузі це - засвоєння професійних і соціальних функцій, активне включення в життя трудового колективу, що $є$ показником певного рівня розвитку соціальної активності. Саме на цих аспектах акцентуватимемо увагу в подальших наукових розвідках.

\title{
Література
}

1. Абрамчук О. Процес виховання студентів університету в позаурочний час / О. Абрамчук, О. Федун // Молодь і ринок. - 2009. - № 9. - С. 32-36. 2. Крягжде С. П. Психология формирования профессиональных интересов / Крягжде С. П. - Вильнюс : Мокслас, 2001. - 195 с. 3. Машбиц Е. И. Психолого-педагогические проблемы компьютеризации обучения / Машбиц Е. И. - М. : Педагогика, 1988. - 192 с. 4. Studies on higher education institutional approaches to teacher education within higher education in Europe : Current models and new developments. - Bucharest, 2003. - 155 p.

$$
\text { УДК 378.015.31:[37.011.3051:78]+784.1 }
$$

Елеонора Кокарева

\section{ДИДАКТИЧНІ УМОВИ ТВОРЧОГО САМОРОЗВИТКУ МАЙБУТНІХ УЧИТЕЛІВ МУЗИКИ (НА ПРИКЛАДІ ВИВЧЕННЯ ДИСЦИПЛІНИ «ХОРОВЕ ДИРИГУВАННЯ»)}

Кокарева Е. О. Дидактичні умови творчого саморозвитку майбутніх учителів музики (на прикладі вивчення дисципліни «Хорове диригування»).

У статті виокремлено евристичне навчання як засіб творчого саморозвитку майбутніх учителів. На цій основі обгрунтовуються дидактичні умови творчого 
саморозвитку студентів музичних факультетів на прикладі однієї 3 профільних дисциплін - хорового диригування.

Ключові слова: дидактичні умови творчого саморозвитку, хорове диригування, майбутній учитель музики.

Кокарева Э. А. Дидактичные условия творческого саморазвития будущих учителей музыки (на примере изучения дисциплины «Хоровое дирижирование»).

В статье выделено эвристическое обучение как средство творческого саморазвития будущих учителей. На этой основе обосновываются дидактические условия творческого саморазвития студентов музыкальных факультетов на примере одной из профильных дисциплин - хорового дирижирования.

Ключевые слова: дидактические условия творческого саморазвития, хоровое дирижирование, будущий учитель музыки.

Kokareva E. O. Didactic conditions for creative self-development of future music teachers (on the example of studying the subject "Choral Conducting").

The author highlights heuristic learning as a means of creative self-development of future teachers. The author also substantiates the didactic conditions for creative selfdevelopment of students studying at musical faculties on the example of one of the core subjects - choral conducting.

Key words: didactic conditions of creative self-development, choral conducting, future music teacher.

Основне завдання сучасного суспільства полягає у формуванні активної особистості, здатної творчо розв'язувати складні професійні питання, постійно саморозвиватись і максимально реалізувати свій внутрішній потенціал. Тому однією iз актуальних проблем навчального процесу в сучасній вищій школі залишається проблема саморозвитку студентів.

Особливо важливого значення зазначене питання набуває в підготовці майбутніх учителів, що самі будуть навчати та виховувати. I від того, наскільки студент готовий до саморозвитку, до творчості, самостійності та незалежності, буде в подальшому залежати й розвиток його учнів. Ми вважаємо, що вирішення окресленого питання можливе на основі виділення та реалізації у навчальному процесі дидактичних умов творчого саморозвитку майбутніх учителів музики.

На основі проаналізованих наукових джерел нами з'ясовано, що дидактичний потенціал евристичного навчання щодо творчого саморозвитку студентів взагалі i майбутніх учителів музики зокрема висвітлено фрагментарно й потребує подальшої розробки. Не вистачає сучасних наукових робіт, які висвітлювали б зазначене питання, окреслювали конкретні дидактичні умови творчого саморозвитку майбутніх учителів музики, потребують розробки й уточнення евристичні методи, прийоми для творчого саморозвитку студентів музичних спеціальностей $з$ урахуванням специфіки дисципліни «Хорове диригування» як однієї з профілюючих.

Mema cmammi- обгрунтування дидактичних умов творчого саморозвитку студентів музично-педагогічних факультетів.

Аналіз науково-педагогічних джерел 3 питань творчого розвитку та саморозвитку (Д. Богоявленська, В. Давидов, Я. Пономарьов, С. Рубінштейн, Л. Савченко, О. Савченко та ін.), евристичного навчання (В. Андреєв, Ю. Кулюткін, В. Лозова, О. Лук, О. Матюшкін, В. Моляко, Д. Пойа, В. Пушкін, А. Хуторський та ін.) та методичної літератури з хорового диригування (Л. Андреєва, Л. Безбородова, 
В. Живов, С. Казачков, В. Соколов, П. Чесноков та ін.) дав змогу виокремити евристичне навчання як засіб творчого саморозвитку майбутніх учителів.

Спираючись на позицію Р. Науризбаєвої [4, с. 118], до дидактичних умов ми відносимо ті, які свідомо створюються в навчальному процесі i які повинні забезпечити його ефективний розвиток та протікання. Стосовно творчої діяльності вважається неправомірним зводити дидактичні умови лише до обставин, до сукупності об'єктів, адже творчий саморозвиток є процесом, який поєднує суб'єктивне та об'єктивне, можливості та прагнення. Тому умова - це не тільки те, що впливає на розвиток, але й те, без чого не може здійснюватися розвиток як такий, що слугує передумовою, основою його виникнення. Чим краще створено умови, тим вищою стає творча діяльність студентів.

Ми вважаємо доцільним упровадження на заняттях 3 хорового диригування евристичного навчання задля творчого саморозвитку студентів, що передбачає нові підходи до організації їх підготовки - навчання на суб'єкт-суб'єктній основі, індивідуалізацію навчальних дій тощо. На цій основі ми виокремили такі дидактичні умови творчого саморозвитку майбутніх учителів музики.

1. Підготовка викладачів до впровадження евристичного навчання на заняттях з хорового диригування.

У процесі діяльності викладача вищої школи виникають різноманітні проблемні ситуації, вирішення яких потребує творчого підходу. Професіоналізм викладача передбачає вміння широко й різноманітно застосовувати теоретичні, дослідні знання у практичній діяльності, інтерес до новинок спеціальної, методичної та загальнопедагогічної літератури.

Завдання 3 названої підготовки викладачів доцільно вирішувати в науковотеоретичному та методичному аспектах. Допомогою при підготовці викладачів $\epsilon$ їх озброєння теоретичною та методичною базою щодо застосування евристичних методів, прийомів, засобів на заняттях з хорового диригування.

Методична підготовка здійснюється у формах бесід із викладачами 3 питань реалізації інноваційних форм та методів роботи, зокрема евристичних, проведення методичних семінарів із зазначеної проблеми, надання порад, вивчення авторських програм евристичного забезпечення навчальних дисциплін та системи пам'яток для викладачів щодо використання евристичних методів та евристичних завдань у професійній діяльності [3].

2. Створення творчого навчального середовища.

Творче навчальне середовище повинно не лише надавати можливість кожному студенту на кожному навчальному етапі розвинути вихідний творчий потенціал, але $\mathrm{i}$ стимулювати потребу в подальшому самопізнанні, творчому саморозвитку, сформувати в нього об'єктивну самооцінку. Основними вимогами до творчого навчального середовища $\epsilon$ високий ступінь невизначеності i проблемності, безперервність та спадкоємність, залучення студента до активної навчальної діяльності.

Творчого саморозвитку неможливо «навчити»,- можна лише забезпечити організацію такого навчального середовища, яке б, грунтуючись на широкому використанні відповідних дидактичних технологій, максимально сприяло саморозвитку студентів.

Змістово-процесуальним забезпеченням організації творчого навчального середовища в нашому дослідженні ми вважаємо евристичне навчання. На заняттях 3 хорового диригування ми пропонуємо застосовувати евристичні методи, прийоми та засоби. У цьому контексті показовим є метод проектів - сукупність прийомів, дій 
студентів у певній послідовності для досягнення поставленої мети [1, с. 26]. Залучення майбутніх учителів музики до проектної діяльності вчить їх самостійно отримувати необхідну інформацію, факти, вміти аналізувати, систематизувати матеріал, висувати гіпотези, робити висновки.

Організація проектної діяльності завжди орієнтована на самостійну роботу студентів та іï результативність. Результати на заняттях 3 хорового диригування мають бути певним чином оформлені, наприклад:

- анотація на хоровий твір;

- відеофільм (відеоколаж) з найяскравіших виступів хорового колективу;

- альбом з фотографіями видатних диригентів, хорових колективів, їх виступів;

- комп'ютерна газета з зазначеної тематики (може включати у себе інформацію про життя та творчість хорових композиторів, диригентів, хорові колективи, хорові ноти тощо);

- доповідь (наприклад, творчість видатних диригентів, важливість техніки диригування, творчі плани хорових колективів тощо);

- «музичний колаж» 3 уривків хорових творів композитора, який би віддзеркалював як образний світ, настрій твору, так і особливості стилю та внутрішнього світу його автора тощо;

- створення власних репертуарних творчих планів колективу (дитячого, аматорського, навчального, професійного), як підготовка до майбутньої професійної діяльності.

Ефективним методом для нашого дослідження $є$ використання на заняттях 3 хорового диригування евристичної бесіди. Цей метод визначають як дієвий для виникнення позитивної мотивації до евристичної діяльності студентів тому, що він $\epsilon$ менш складним у використанні порівняно з іншими евристичними методами; процес контролює викладач, тому відпадає можливий страх студентів при зіткненні 3 невипробуваними для себе видами діяльності тощо.

Евристична бесіда є системою взаємопов'язаних запитань, кожне 3 яких служить кроком на шляху до розв'язання проблеми, коли студенти не тільки відтворюють отримані знання, а й здійснюють пошук. Уважаємо, що завдяки впровадженню нами цього методу студенти матимуть можливість спостерігати за процесом розв'язання проблеми, проникаючи вглиб неї, прослідковувати та осмислювати необхідні етапи їі розв'язання та виявляти загальні методи вирішення завдань, які переноситимуть в інші евристичні бесіди, а згодом будуть розв'язувати творчі завдання більш самостійно у процесі використання евристичних методів навчання.

Евристичне навчання має глибокі діалогічні основи, оскільки створення студентами власних освітніх продуктів, їх творча самореалізація, саморозвиток можливі лише в діалозі із зовнішнім освітнім середовищем, тому використання евристичного діалогу на заняттях допоможе формувати евристичні якості студента, впливатиме на ефективність навчального процесу. За допомогою методу евристичного діалогу майбутні вчителі вчаться ставити запитання, що передбачає розвиток у них логічного й образного мислення, активність на заняттях, бажання i здатність здобувати інформацію. Зазначена вище діяльність важлива й тим, що сприяє значному розширенню освітнього кругозору майбутнього вчителя, що є необхідним для його професійного становлення.

Необхідно зазначити, що важливими допоміжними засобами в розв'язанні евристичних задач, що сприятимуть творчому саморозвитку, ми вважаємо використання системи евристик В. Андреєва та навідних запитань Д. Пойа. 
Застосування цих засобів - так званих стандартизованих завдань та запитань, що складені в логічній послідовності для більш ефективного та швидкого розв'язання задач, виникаючих проблем - сприяє інтересу студентів, позитивному ставленню до них, полегшуючи роботу майбутніх учителів, тому що мають шляхи вирішення питання, іiі докладні етапи й розвивають мислення студентів, впливають на їх розвиток та в майбутньому - саморозвиток.

Педагогічна практика свідчить, що багато видатних педагогів, педагогівноваторів використовували у своїй діяльності прийом віри в сили особистості, прагнули викликати почуття радощів та забезпечити успіх у навчанні. Ситуація успіху - це суб'єктивний психічний стан задоволення наслідком фізичної або моральної напруги виконавця справи, творця явища [5, с. 198]. Ситуація успіху досягається тоді, коли студент сам визначає цей результат як успіх. Завдання педагога - допомогти студентові зростати «в успіху», дати можливість відчути радість від подолання труднощів та зрозуміти, що для цього необхідно докласти сил - успіх буде еквівалентним витраченим зусиллям. Майбутні вчителі, які у процесі навчання стикалися із ситуаціями успіху, пережили відчуття емоційного піднесення, віри у свої сили, самі здатні будуть створити ситуації успіху для учнів під час професійної діяльності.

3. Побудова індивідуальної програми творчого саморозвитку студента.

Для студентів, які закінчують вищий навчальний заклад, одним із головних питань $є$ вибір подальшого життєвого шляху. Багато з них, хоч і навчаються за вже обраним напрямом, все ще не визначилися зі своїм майбутнім працевлаштуванням.

Практика показує, що складання індивідуальної програми творчого саморозвитку сприяє підтриманню найбільш доцільного режиму роботи та активності творчої особистості при формуванні задуму, визначенні шляхів розв'язання завдань, сприяє підвищенню культури мислення тощо.

Для побудови індивідуальної програми творчого саморозвитку для майбутнього вчителя музики на заняттях 3 хорового диригування важливим моментом $\epsilon$ запровадження, поряд із педагогічною оцінкою, системи самооцінки власних досягнень, одним із шляхів якого є складання та ведення портфоліо.

Одним із завдань нашої роботи є підвищення мотивації студентів до творчого саморозвитку. Ми прагнемо не лише відобразити кінцевий результат їх саморозвитку, a й показати процес досягнення цих змін. Саме тому ми надаємо перевагу запровадженню й веденню портфоліо як форми самооцінки власних досягнень. Крім того, портфоліо забезпечує зворотній зв'язок із викладачем у процесі творчого саморозвитку майбутніх учителів.

У зарубіжній літературі портфоліо визначається як колекція робіт особистості, що демонструє результати іiі діяльності, прогрес і досягнення в різних сферах. Г. Восканян зазначає, що мета створення портфоліо - визначення динаміки значущих самоосвітніх результатів у цілому, відслідковування індивідуального прогресу студента в навчальному процесі, демонстрація його здібності до практичного застосування отриманих знань [2, с. 25-26].

Портфоліо дає змогу розв'язувати низку таких поставлених нами завдань:

- розвинути й постійно підтримувати мотивацію, готовність майбутніх учителів до творчого саморозвитку;

- розвинути рефлексивну й самооцінювальну діяльність;

- фіксувати зміни й зростання за певний час;

- забезпечити неперервність творчого саморозвитку. 
Для підвищення ефективності занять 3 хорового диригування, ми вважаємо доцільним розміщувати в портфоліо студентів:

- рефлексивні запитання й письмові відповіді на них після кожного заняття, щоб студент міг прослідкувати власний розвиток (наприклад, «Які завдання ви перед собою ставили, коли диригували цей твір?», «Проаналізуйте - що вийшло, а що ні і чому?», «Що я робив для того, щоб підвищити власний професійний рівень, до чого прагнув (озвучуючи способи дії)», «Який у мене був диригентський рівень на початку заняття?», «Який професійний рівень у мене в кінці заняття, яких знань, умінь, навичок я набув?»);

- анотації на хорові твори;

- опис результатів заліків, іспитів з аналізом та рекомендаціями для покращення їх у майбутньому;

- аудіо-, відео- та фотоматеріали з власних виступів тощо.

Цілеспрямована робота 3 портфоліо сприятиме підвищенню професійного диригентського рівня студента, навчить його важливому процесу ставити перед собою цілі, самостійно визначати засоби та досягати їх. У портфоліо можна помістити i слабкі роботи. Системна робота із портфоліо посилює ефективність діяльності 3 творчого саморозвитку, сприяє здійсненню інформаційного пошуку, мотивує на співвідношення власних домагань та інтересів інших людей, підвищує рівень критичності в самооцінці, дає змогу цілеспрямовано здійснювати моніторинг індивідуальної програми творчого саморозвитку кожного майбутнього вчителя.

Описані дидактичні умови творчого саморозвитку взаємодоповнюють одна одну, перебувають у послідовній взаємозалежності. Їх дотримання передбачає організацію методичних семінарів для викладачів із питань застосування евристичних методів, прийомів на заняттях 3 хорового диригування; формування мотивації до творчого саморозвитку під час організації евристичного навчання, активізацію пізнавальних процесів, розвиток рефлексії у майбутніх учителів; вироблення у студентів особистісного ставлення до майбутньої професійної діяльності, оволодіння ними системою знань та вмінь щодо фіксації основних освітніх орієнтирів.

Наше дослідження не вичерпує всіх аспектів творчого саморозвитку майбутніх учителів музики на заняттях 3 хорового диригування. Потребують подальшого вивчення проблеми творчого саморозвитку в інших видах навчальної діяльності, необхідно дослідити умови творчого саморозвитку школярів та методичні аспекти підготовки майбутніх учителів музики до організації евристичного навчання.

\section{Література}

1. Бритикова Г. В. Метод проектів як сучасна педагогічна технологія / Г. В. Бритикова, К. К. Медведик, О. Б. Яйцева, О. І. Амброва // Управління школою. 2008. - № 7. - С. 26-28. 2. Восканян Г. Г. Портфоліо як форма оцінки результативності самоосвітньої діяльності вчителя / Г. Г. Восканян, Р. Д. Самоздра. Управління школою. - 2008. - № 1. - С. 25-28. 3. Кокарева Е. О. Евристичне навчання як засіб творчого саморозвитку майбутніх педагогів : дис. ... канд. пед. наук : 13.00.09/ Е. О. Кокарева; Криворізький педагогічний інститут ДВНЗ «Криворізький національний університет».- Кривий Ріг, 2012. - 258 с. 4. Наурызбаева Р. Н. Педагогическая система эвристического обучения учащихся художественно-творческой деятельности средствами народного искусства : дис. ... докт. пед. наук : 13.00.01/ Р. Н. Наурызбаева; Казанский государственный университет им. В. И. Ульянова-Ленина. - Казань, 2009. - 543 с. 5. Освітні технології : [навч.-метод. посіб.] / О. М. Пєхота, А. З. Кіктенко, О. М. Любарська та ін.; заг. ред. О. М. Пєхоти. - К. : А.С.К., 2001. - 256 с. 